\title{
The Effect of Blood Sugar Variation on the \\ Urinary Excretion of Catecholamines
}

\author{
By
}

\author{
Ikuo MASUTANI \\ The 2nd Department of Internal Medicine, Osaka University Medical School \\ (Director : Professor T. Kitani)
}

It has been well established that catecholamine excretion in urine increases after insulin administration; and the reduction of blood sugar below the normal range is considered to be the stimulant of catecholamine secretion. However, the hypoglycemic syndrome is occasionally encountered under insulin treatment of diabetics even when the blood sugar remains within normal range, and it is reasonably assumed that there is an increased discharge of catecholamine under such a condition. In this report, the relation between blood sugar variation and the excretion of catecholamine was analysed in normal subjects and patients with various severities of diabetes mellitus. The mechanism of increasement of catecholamine excretion was also investigated. The results were as follows :

1) The folds of increment in catecholamine excretion after the intravenous administration of insulin of $0.1 \mathrm{unit} / \mathrm{kg}$ to normal or diabetic subjects is significantly well correlated with the value represented as the following equation;

(blood sugar before administration)-(minimum blood sugar value)

(blood sugar before administration $) \times($ minutes from adm. to minimum)

2) The transient increase of urinary catecholamine metabolites such as Metanephrine or Vanillylmandelic acid is observed in the early period of the treatment of diabetics with insulin or antidiabetic sulfonylurea.

3) The data was obtained in animal experiments, suggesting that the adaptation of the central nervous system to hypoglycemic state is the cause of the increased excretion of catecholamine observed in diabetics when the blood sugar remains within normal range after insulin administration.

\section{Inhibitory Effects on the Thyroid in Young Rats of Excessive Fecal Thyroxine Excretion}

\section{Tetsumaru SASAKI, Hironori NAKAJIMA, Tadao Makino, Hiroo Niimi, Masaaki KURAMOGHI, Junzo KAMIMAKI, Yasuhiko FUKUMOTO, Yoshiyuki SHIOKAWA, Mitsunori MURATA, Masumitsu NAKADA, Susumu MATSUMOTO and Fuku Watanabe}

\author{
Department of Pediatrics, School of Medicine, Chiba University
}

1) Fecal excretion of thyroxine increased greatly when young rats were fed powdered cellulose, barium sulfate or clay, added to the basal diet and then injected with $\mathrm{I}^{131}$-thyroxine.

2) A significant decrease in the thyroidal uptake of $\mathrm{I}^{131}$ occurred in 4 days. After 2 months on these diets, marked decreases in the weights of the thyroid glands and in $\mathrm{I}^{131}$ uptake, as well as

Vol. 38 No. 9 


\title{
血糖変動時の尿中 Catecholamine の消長に関する研究
}

\author{
大阪大学医学部第二内科学教室（主任 木谷威男教授） \\ 栘谷郁男
}

(昭和 37 年 7 月 2 日受付)

\begin{tabular}{|c|c|}
\hline 目 & 次 \\
\hline 第 1 章 緒 論 & 第 2 項 実験成績 \\
\hline $\begin{array}{c}\text { 第 } 2 \text { 章 尿中 Catecholamine 及びその代謝 } \\
\text { 産物の測定法 }\end{array}$ & $\begin{array}{l}\text { 第 } 3 \text { 節 2-Deoxyglucose 静注实験 } \\
\text { 第 } 1 \text { 項 実験方法 }\end{array}$ \\
\hline 第 1 節 Catecholamine の测定法 & 第 2 項 实験成績 \\
\hline 第 2 節 Metanephrine, Normetanephrine & 第 4 節 2-Deoxyglucose 頸動脈注射実験 \\
\hline の測定法 & 第 1 項 実験方法 \\
\hline 第 3 節 Vanillyl mandelic acid の測定 & 第 2 項 実験成績 \\
\hline 法 & 第 5 節 両側副腎神経切断家束に対学る \\
\hline 第 3 章 臨床実験 & 2-Deoxyglucose 静注実験 \\
\hline 第 1 節 実験対象 & 第 1 項 実験方法 \\
\hline 第 2 節 実験方法 & 第 2 項 実験成績 \\
\hline 第 3 節 実験成績 & 第 6 節 Insulin 静注時血糖降下总防止し \\
\hline 第 4 章 動物実験 & た場合の Adrenalin 排泄 \\
\hline 第 1 節 研究対象及び資料採集方法 & 第 1 項 実験方法 \\
\hline 第 2 節 Alloxan 糖尿家鬼の血糖変動と & 第 2 項 実験戊績 \\
\hline Adrenalin 排泄 & 第 5 章 総括並びに考按 \\
\hline 第 1 項 実験方法 & 第 6 章 結 論 \\
\hline
\end{tabular}

第 1 章 緒

論

低血糖症状と副腎髄質分泌との関係については早期より検討が進められており，1924年 Cannon 等1) は猫 で Insulin 静注後, 副腎摘除処置をほどてせる場合にその心搏の変化を来さないととより, Insulin による 心搏促進は心臓に対す Insulin の直接作用ではなく, Insulin による血糖降下の結果，神経刺战を介する副

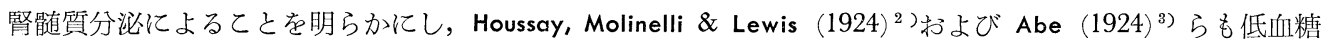
が副腎髄質の分泌刺㦸となるととを報じている. 又 Insulin 投与時の血中或は尿中 Catecholamine (CA と 略記す) の消長についても Burn 等 ${ }^{4)}$, Elmadjian 等 ${ }^{5}$, Euler \& Luft ${ }^{6}$, Pitkänen 等 ${ }^{7}$ の報告がみられ, Insulin 低血糖はむしろ副腎髄質ホルモンの分泌機構の研究に好都合な実験条件を提供するものとして広く利用され ている.しかしながらこうした場合 Insulin の投与量が一般に大量であり，また研究対象はすへて正常人， 正常動物に限られていて，血糖が正常値以下に迄低下するととが CA の分泌刺㦸となると考えられてきた。 即ち問題が全て「Insulin 低血糖と CA 分泌」という面に限定されており，糖尿病患者を含めた広い範用の 血糖值の変動と CA 分泌との関係を追求した報告は今日まで余り見当らない. しかし臨床上糖尿病患者を Insulin その他の血糖降下剤により治療を行なつている際に, 血糖の降下が正常範囲以下には至らなかつた 場合にも，時に低血糖時の症状の発現するてとが経験され，てういつた際にも CA 分泌の充進があると推 
定される。

一方 Adrenalin (A と略記す) の測定は，Loew ${ }^{9}$ ），Paget ${ }^{9}$ )がアルカり溶液中にてAが強い螢光を発する 事実を報告して以来，乙れを利用せる CA の微量螢光定量法に対する研究が進められ 3.5.6-Trihydroxyindole (Adrenolutin と Noradrenolutin) を生成して, 紫外線で強い黄緑螢光を発生させる Trihydroxyindole 法 (Lund 法 $^{10)}$, Euler \& Floding 法 $^{11)}$ ), Adrenochrome 酒化させた後, その Catechol 核へ Ethylenediamine を縮合させ，生成せられたる螢光物質を測定する Ethylenediamine 法 (Weil-Mrlharbe \& Bone 法 $\left.{ }^{12}\right)$ が提唱され，更に最近その優れた改良法も報告されている ${ }^{13)}{ }^{14)}$. 又近年 CA の生理的意 義か注目されると共にその生合成，代謝椂式も深く研究され circulating CA の代謝主要経路が，先ず catechol-o-methyl transferase により 3 位の $\mathrm{OH}$ 基が methylate せられて Metanephrine (MA と略記 す), Normetanephrine (NM と略記す)となり，その後 Monoamine oxidase の作用を受けて 3-methoxy, 4-hydroxy mandelic acid (VMA と略記す) となるものであるととが Axelrod ${ }^{15)}$ らにより解明され，乙 うした中間及び終末代謝産物に対する測定法及び其の改良法の数々が発表されている ${ }^{16) ~ 21) . ~}$

そてでかかる測定法を応用し，糖尿病患者を含めた広い範囲の血糖值の変動之原中 CA 及びその代㴬産 物の消長との関係を分析し，更に血桾降下時の副腎髓質分泌元進の機序についても検討を行なつた。

\section{第 2 章 尿中 $\mathbf{C A}$ 及びその代謝産物の測定法}

\section{第 1 節 CA の測定法}

CA の測定には，初期には主として生物学的方法が用いられていたが，螢光を応用せる微量定量法の検討 が進み，今日ではほとんどこの螢光法が使用されている。この微量螢光定量法にも，Trihydroxyindole 法 (THI 法と略記す) と Ethylenediamine 法 (ED 法と略記す) との二種があり，特異性という点では前 者がすぐれ，鋭敏度では後者が勝つている。佐野等 ${ }^{13)}$ はアルミナ吸着後, 弱酸による溶计液をさらに Amberlitec G-50 カラムに流して，その Filtrate および湓陵による Eluate に THI 法と ED 法とを併用し， この際 THI 法においては酸化剂使用により pH3.5では Noradrenalin (NA と略記す) はほとんど酸化 されることなく Aのみか酸化されて Adrenolutin となるが，pH6.0では A, NA 其に酸化を受けて夫々の Lutin となり螢光を発するので，乙れを応用して A, NA の分離定量を行ない，且つ 3-Hydroxytyramine= Dopamine (DA と略記す)，その他の酸吽および中性：Catechol 休よ分雨定量した。にてで著者はかかる定 量法に集じて尿中 CA 在測定した。

\section{[試薬および操作〕}

採尿は褐色瓶を使用し、あらかじめ少量の濃硫酸抢よび EDTA を投入しててれに集めた。 この尿 $100 \mathrm{ml}$ に酸処理をほどてせるアルミナ $2.5 \mathrm{~g} と 2 \%$ BTB アルコール溶液数㵜を加光 magnetic stirrer により攪拌 しながら $20 \% \mathrm{NaOH}$ を滴下し，青色になると更に5\% NaOH を加光，Test Paper GR (東洋濾紙) にて pH8.5亿調整する。更に5 分間 stirring を続けその後静品して上静を傾潟する。乙れに $\mathrm{NaOH}$ にて $\mathrm{pH}$ 8.5 亿調整した水を注ぎ洗いながらグラスフィルター（No. 3 )上に移す。 $0.2 \mathrm{~N}$ 醋酸 $9 \mathrm{ml}$ てれに注ぎアル ミナに吸着された Catechol 体を $10 \mathrm{ml}$ の目盛付小試験管内に溶出する.

そこでこのアルミナの醋酸溶出液に重炭酸ソーダを加えて $\mathrm{pH} 6.5$ 亿調整し, 水在追加して $10 \mathrm{ml}$ とせる後 Amberlite CG-50 カラム $\left.{ }^{19}\right)(0.7 \times 10 \mathrm{~cm})$ 亿通ずる。続いて $0.2 \mathrm{M}$ 燐酸ナトリウム緩衝液 $(\mathrm{pH} 6.5) 10 \mathrm{ml}$ で洗う。ての両 Filtrate を合して DOPA 並びにその他の酸性及び中性 Catechol 体測定に使用する. 次 そ N-HCl 15ml を流し，別に Eluate として A, NA おょび DA の測定に使用する.

定量:

1) THI 法

第 1 表の如く上記の Filtrate から Blank, Sample, Sample + DOPA の内部規淮滩を作成し，フェリシ ァン化カリにより酸化後アスコルビン酸を加え，てれにて発生せる營光を Photovolt 社製品 Model 540, 一次フィルター B-Hg 1, 二次フィルターB-520を使用して測定, 又 Eluate から第1表の如く Blank, 
第 1 表 THI 法の操作 (数字 $\mathrm{ml}$ )

\begin{tabular}{|c|c|c|c|c|c|c|c|c|c|c|}
\hline \multicolumn{4}{|c|}{ Filtrate } & \multicolumn{7}{|c|}{ Eluate } \\
\hline & \multirow{2}{*}{ Blank } & \multirow{2}{*}{ Sample } & \multirow{2}{*}{$\begin{array}{l}\text { Sample } \\
\text { 及 び } \\
\text { DOPA }\end{array}$} & \multirow{2}{*}{ Blank } & \multicolumn{2}{|c|}{ Sample } & \multicolumn{2}{|c|}{$\begin{array}{l}\text { Sample } \\
\text { 及び A }\end{array}$} & \multicolumn{2}{|c|}{$\begin{array}{r}\text { Sample } \\
\text { 及びNA }\end{array}$} \\
\hline & & & & & \multicolumn{6}{|c|}{$\mathrm{pH} 3.5 \mathrm{pH} 6.0 \mathrm{pH} 3.5 \mathrm{pH} 6.0 \mathrm{pH} 3.5 \mathrm{pH} 6.0$} \\
\hline Sample & 2.0 & 2.0 & 2.0 & 1.5 & 1.5 & 1.5 & 1.5 & 1.5 & 1.5 & 1.5 \\
\hline 水 & 0.4 & 0.2 & - & 0.4 & 0.2 & 0.2 & - & - & - & - \\
\hline $1 \mathrm{M}_{\text {酸 }}|\mathrm{pH} 3.5|$ & - & - & - & - & 1.0 & - & 1.0 & - & 1.0 & - \\
\hline 緩 衝 液 $\mathrm{pH} 6.0$ & - & - & - & 1.0 & - & 1.0 & - & 1.0 & - & 1.0 \\
\hline $\begin{array}{l}\text { DOPA，A，また } \\
\text { はNA }(1 \gamma / \mathrm{ml})\end{array}$ & - & - & 0.2 & - & - & - & 0.2 & 0.2 & 0.2 & 0.2 \\
\hline $0.5 \% \mathrm{ZnSO}_{4}$ & - & 0.1 & 0.1 & - & 0.1 & 0.1 & 0.1 & $0 . \mathrm{I}$ & 0.1 & 0.1 \\
\hline $\begin{array}{l}0.25 \% \text { フェり } \\
\text { シアン化カリ }\end{array}$ & - & 0.1 & 0.1 & - & 0.1 & 0.1 & 0.1 & 0.1 & 0.1 & 0.1 \\
\hline \multicolumn{11}{|c|}{$5 \mathrm{~min}}$. \\
\hline $\begin{array}{l}\text { アルカリ性 } \\
\text { アスコルビン酸 } \\
\text { 溶 }\end{array}$ & 1.0 & 1.0 & 1.0 & 1.0 & 1.0 & 1.0 & 1.0 & 1.0 & 1.0 & 1.0 \\
\hline $\begin{array}{l}\text { 各試 鈳 管の } \\
\text { 财光度の読み }\end{array}$ & $\mathrm{x}$ & y & $\mathrm{z}$ & $\mathrm{a}$ & $\mathrm{b}$ & $\mathrm{c}$ & $\mathrm{d}$ & $\mathrm{e}$ & $f$ & $\mathrm{~g}$ \\
\hline
\end{tabular}

* 測定時 $2 \%$ ア

Sample, Sample+A（又は NA）の内部規準液を作成，更に後 2 者は各々 2 群に分ち醋酸緩衝液にて $\mathrm{pH}$ 3.5及び pH6.0亿調整し，Filtrate の時と同様と螢光を発生せしめてれを測定する.

なお以上の操作中 Blank はフェリシァン化力リの酸化を除く全操作を加えたものである。

2) $\mathrm{ED}$ 法

Filtrate および Eluate 夫々 $5 \mathrm{ml}$ Ethylenediamine dihydrochloride $0.25 \mathrm{ml}$, Ethylenediamine hydrate $0.5 \mathrm{ml}$ を加え, 一昼夜室温に放置し, 翌日食塩 $2 \mathrm{~g}$ を投し， Isobutanol $3.5 \mathrm{ml}$ で抽出し，一次フィルタ - B-Hg 2, 3, 二次フィルター B-540を使用し測定する。乙の場合他に水及び A, NA, DA の各規準液に ついも同様の操作を行なう。

計算 :

上記測定によつて得られた值は，次式により計算する。(符号は第 1 表参照)

THI 法より

$$
\begin{array}{ll}
\text { DOPA } & (r / \mathrm{dl})=\frac{\mathrm{y}-\mathrm{x}}{\mathrm{z}-\mathrm{y}} \times 2 \\
\text { A } & (r / \mathrm{dl})=\frac{\mathrm{b}-\mathrm{a}}{\mathrm{d}-\mathrm{b}} \times 2.13 \\
\text { NA } \quad(r / \mathrm{dl}) & =\frac{(\mathrm{c}-\mathrm{a}) \times 2.13-(\mathrm{e}-\mathrm{c}) \times \mathrm{A}}{\mathrm{g}-\mathrm{c}}
\end{array}
$$

ED 法より

DA $(\gamma / \mathrm{dl})=\frac{(\text { Eluate } の \text { Sample })-\left(\mathrm{A} \times \frac{\mathrm{A} \text { のStandard }}{16}+\mathrm{NA} \times \frac{\mathrm{NA} の \text { Standard }}{16}\right)}{\text { DA } の \text { Standard }} \times 16$

その他の酸性及び中性 Catechol 体 $(r / \mathrm{dl})=\frac{\text { Filtrate } の \text { Sample }}{\mathrm{A} の \text { Standard }} \times 10.7$

(ED 法の場合各々の値は Blank を引いたもの) 
第 2節 MA, NM の測定法

MA, NM の測定は Pisano ${ }^{16}$ の発表せる方法によつた. 即ち MA, NM は大部分 Conjugated form と して尿中に排泄されるので ${ }^{22)}$ ，先ずてれを水解してから Amberlite CG-50亿吸着させ，次いでその Eluate に $\mathrm{NaIO}_{4}$ を反応させ Vanillin を生成せしめ，乙れを比色定量する。

\section{[試薬および操作]}

先ず尿を Toluene 存在下に集め，必要であれば濾過する。定量にはこの $10 \mathrm{ml}$ を使用する。 $6 \mathrm{~N}-\mathrm{HCl}$ を 加え Test Paper CR (東洋滤紙) にて pH0.9亿調整し，栓付試験管に入れ20分間沸騰水中に入れ結合型 MA，NM を水解せしめる。 そして冷却した後 $1 \mathrm{~N}-\mathrm{NaOH}$ にて Test Paper MR (東洋滤紙) を使用して $\mathrm{pH} 6.0$ ～6.5亿調整しててれに水を加えて $20 \mathrm{ml}$ とする。一方 Glass wool で栓をせるカラムに Amberlite CG-50（pH 6.0-6.5 ${ }^{16)}$ ⿸ $1 \times 5 \mathrm{~cm}$ つめ，乙れに水 $15 \mathrm{ml}$ を流して緩衝液を洗う。乙の Resin カラムに前 記の水解尿を通し，ついで15〜20 ml の水を流す。最後に $4 \mathrm{~N}-\mathrm{NH}_{4} \mathrm{OH} 10 \mathrm{ml}$ にてカラムに吸着された MA, NM 学溶出する.

この Eluate に $4 \mathrm{~N}-\mathrm{NH}_{4} \mathrm{OH}$ を加えて $10 \mathrm{ml}$ となしててれを $4 \mathrm{ml}$ ずつ 2 本の試験管に分け，一方には水 $0.1 \mathrm{ml}$ を入れ Blank とし，他の一方には Periodate 溶液 $\left(2 \% \mathrm{NaIO}_{4}\right) \quad 0.1 \mathrm{ml}$ を加える。規準液 $(1 \mathrm{ml}$ の $4 \mathrm{~N}-\mathrm{NH}_{4} \mathrm{OH}$ 中に Vanillin $1 \gamma$ を含む) そついても同様にする。但しこの際 MA， NM は分離されない ので以後は MA, NM を含めて MA 值として表わした.

計算 :

MA $(r / \mathrm{ml})=\frac{(\text { Sample のよみ })-(\text { Blank のよみ })}{(\text { 規集液のよみ })-(\text { Blank のよみ })} \times 1.29$

第 3 節 VMA の測定法

VMA の測定法は Paper-Chromatography 法 ${ }^{19)}$ ，高压濾紙電気泳動法 ${ }^{20}$ および Sandler 法 ${ }^{21)}$ がある. 著者は Sandler 法に従つた.

尿を Dowex $1 \times 2$ 亿通し，VMA 存吸着せしぬ，醋酸緩衝液で溶出した後醋酸エチルで抽出，低圧蒸溜 乾固し，稀硫酸を加えアルミナを触媒として Autoclave 中で反応せしめVMA を Vanillin に転換する。 この Vanillin を Indol により発色せしめその吸光度より VMA を計算する。

\section{〔試薬および操作〕}

尿 $1.0 \mathrm{ml}$ を Dowex $1 \times 2$ カラム $(0.5 \times 10 \mathrm{~cm})^{21)}$ に流し，更に蒸溜水 $30 \mathrm{ml}$ を流してカラムを洗う。次に $1 \mathrm{M}$ 醋酸アンモニウム緩衝液（pH4.8） $15 \mathrm{ml}$ 在通じ，その溶出液を分液漏斗にとる。乙れに $50 \% \mathrm{H}_{2} \mathrm{SO}_{4}$ を

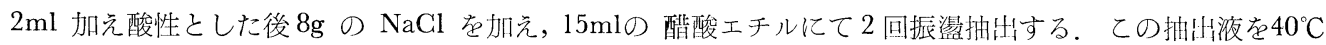
にて低温減圧下に蒸発乾固せしめ，乙れに $5 \% \mathrm{H}_{2} \mathrm{SO}_{4} 2.5 \mathrm{ml}$ を加え溶解せしめる。乙れに0.2g の活性ア ルミナを加え Autoclave 中にて $15 \mathrm{lb} / \mathrm{inch}^{2}$, 60分閒反応せしめる。其後てれを逶沈してその上清 $1.5 \mathrm{ml}$ をと り正燐酸 $2.4 \mathrm{ml}$, Indol 試薬 (Indol $50 \mathrm{mg}$ を $10 \mathrm{ml}$ Ethanol 飞溶解) $0.1 \mathrm{ml}$ 老加光，5分以内に $945 \mathrm{~m} \mu$ の吸光度を測定する.

この祭 Blank として $5 \% \mathrm{H}_{2} \mathrm{SO}_{4} 1.5 \mathrm{ml}$ および Vanillin 規淮液 $\left(5 \% \mathrm{H}_{2} \mathrm{SO}_{4} 1 \mathrm{ml}+12.5 \gamma\right.$ の Vanillin を含む） $1.5 \mathrm{ml}$ にも正燐酸，Indol 侙薬を同様に加えて测定する.

計算 :

$$
\text { VMA }(\mu \mathrm{g} / \mathrm{ml})=\frac{(\text { Sample のよみ })-(\text { Blank のよみ })}{(\text { 規準液のよみ })-(\text { Blank のよみ })} \times 8.15
$$

\section{第 3 章 臨 床 実 験}

\section{第 1 節 実験対象}

当内科に通院或いは入院し，routine の臨床検查を完了した上，糖尿病又は正常と部断された20例を刘象 とした，但し糖尿病の場合，顕著なる循環障㥂，婜障碍，肝障㥂を有するものは含んでいない． 


\section{第 2 節 実験方法}

上記の正常人および糖尿病患者を早朝より絶食にせしめ, 臥床または非臥床にして安静状態にし, 午前 7 時に放尿後午前 9 時に採尿, 前 2 時間尿とし, 同時に Regular Insulin 体重 $\mathrm{kg}$ 当り 0.1 単位静注する.そ して其後は 2 時間ずつ 2 回採尿し，乙の 3 資料について尿 Catechol 体を分画定量し，前值を1.0としてそ の変動を検討した。この際 Insulin の代りに生理的食塩水を静注した対照例では，尿 Catechol 体に大きな 変動のないことを予め確めた。

I血糖值は Insulin 静注前，および静注後20分，30分，60分，90分，120分に測定した。午糖測定法は Somogyi-Nelson 法によつた.

\section{第3 節 実験成績}

尿中 $\mathrm{A}$ 排泄は，第 2 表に示す如く一般に著しい増量を示し，正常人ではしばしば前値の 5 〜 佯に達し萻

第 2 表 Insulin 0.1I.U./kg 静注時の血桾及び尿中 CA 排泄* （正常人及び糖尿病患者）

\begin{tabular}{|c|c|c|c|c|c|c|c|c|c|}
\hline \multirow{2}{*}{ No. } & \multicolumn{2}{|c|}{ 血糖値 $\mathrm{mg} / \mathrm{dl}$} & \multirow{2}{*}{ A } & \multirow{2}{*}{ A N } & \multirow{2}{*}{ D A } & \multirow{2}{*}{ DOPA } & \multirow{2}{*}{\multicolumn{2}{|c|}{$\begin{array}{l}\text { その他の酸 } \\
\text { 中 性 catechol }\end{array}$}} & \multirow{2}{*}{$\begin{array}{l}\text { 性 } \\
\text { 体 }\end{array}$} \\
\hline & 前 & (先) 後 & & & & & & & \\
\hline 1 & 140.0 & (30) 57.5 & 2.59 & 1.29 & 1.25 & 0.92 & & 0.89 & \\
\hline 2 & 153.0 & (30) 93.8 & 1.43 & 1.02 & 1.04 & 0.68 & & 0.96 & \\
\hline 3 & 159.6 & (30) 96.9 & 2.24 & 0.82 & 1.01 & 0.46 & & 0.89 & \\
\hline 4 & 126.1 & (30) 85.4 & 2.82 & 1.66 & 1.54 & 0.86 & & 0.98 & \\
\hline 5 & 178.9 & (30) 155.2 & 0.96 & 0.77 & 0.95 & 1.02 & & 0.79 & \\
\hline 6 & 126.1 & (30) 82.7 & 2.08 & 1.23 & 1.31 & 1.30 & & 0.94 & \\
\hline 7 & 253.0 & (90) 232.0 & 1.22 & 0.81 & 1.50 & 1.49 & & 1.04 & \\
\hline 8 & 163.0 & (30) 98.5 & 1.98 & 1.07 & 1.25 & 0.73 & & 1.07 & \\
\hline 9 & 90.1 & (30) 46.9 & 5.22 & 2.82 & 2.60 & 1.36 & & 1.63 & \\
\hline 10 & 96.2 & (30) 54.1 & 6.25 & 2.11 & & 1.67 & & 3.71 & \\
\hline 11 & 287.0 & (30) 278.0 & 1.15 & 1.56 & 1.36 & 1.56 & & 1.69 & \\
\hline 12 & 164.0 & (10) 106.0 & 3.37 & 1.69 & & & & & \\
\hline 13 & 122.0 & (30) 63.0 & 2.81 & 1.90 & & & & & \\
\hline 14 & 92.1 & (30) 45.2 & 2.54 & 1.41 & & & & & \\
\hline 15 & 125.0 & (30) 83.0 & 1.91 & 0.83 & & & & & \\
\hline 16 & 200.3 & (20) 134.1 & 2.13 & 1.39 & & & & & \\
\hline 17 & 157.0 & (30) 57.0 & 4.54 & 1.16 & & & & & \\
\hline 18 & 172.0 & (30) 75.0 & 1.16 & 0.98 & & & & & \\
\hline 19 & 176.0 & (30) 156.0 & 1.06 & 1.32 & & & & & \\
\hline 20 & 93.0 & (20) 39.0 & 3.15 & & & & & & \\
\hline
\end{tabular}

* CA は Insulin 静注後の 2 時間尿々静注前 2 時間尿との比

** 最低值徍した時間（分）

明な例では臨床症状として心悸穴進，冷汗等を認めた，糖尿病患者に於ても正常人に比し一般にやや軽度で はあるが，Aの増量は明らかに認められた。そして血糖の降下が必らずしも「低血糖」の範囲までおよばなく ともA 增量を認め, この現象は糖尿病患者においてむしろ一般的であつた (第 1 汹)．Ａの增量は概ね注射 後最初の 2 時間内におてるが，時に糖尿病患者においてやや遅れて発現するてとがあつた．

しかし一方血糖降下の起らなかつた例では見るべきA排泄増加はなかつた (第 2 閂)。乙てでAの変化につ いて，血糖変動に関する諸量との関係を検討した所

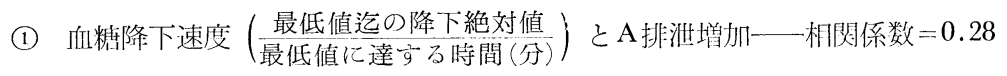


第 1 図 “位血糖”経ず Adrenalin の増量した例 秋 $○$ 古40才 松 $\bigcirc$ 与令30才
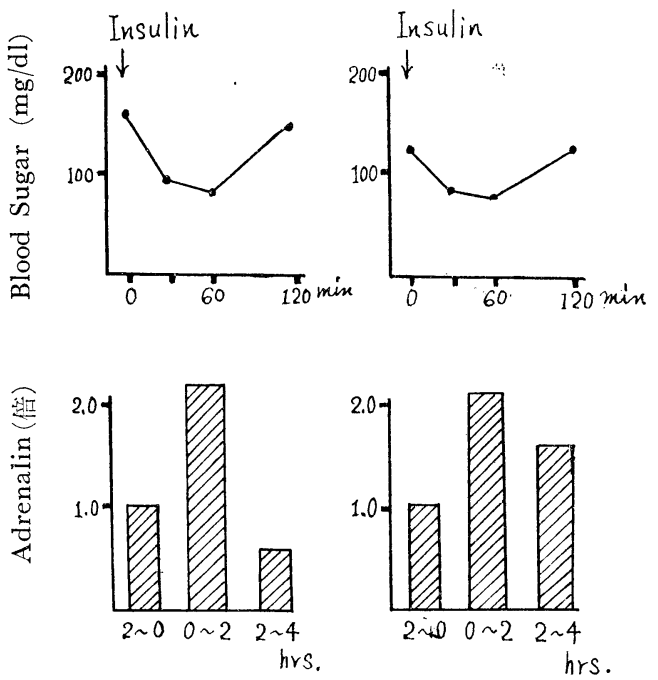

第 2 図 Insulin 感性の極めて覀い例 木○须○ 우49才 馬○晴○含56才

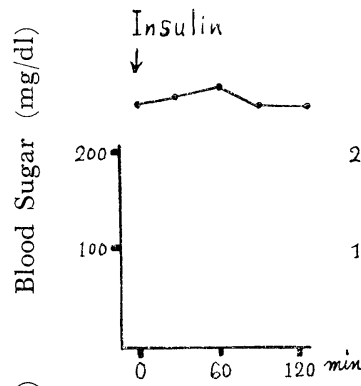

Insulin $\downarrow$
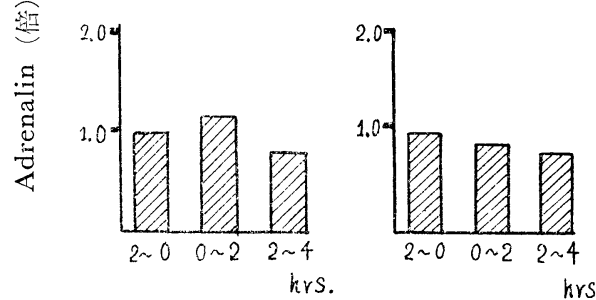

(2) 血糖降下率 $\left(\frac{\text { 最低値迄の降下絶対值 }}{\text { 前 值 }}\right)$ ¿ $\mathrm{A}$ 排泄增加——相関係数 $=0.47$

(3) 単位時間に於ける血糖降下率 $\left(\frac{\text { 最低值迄の降下絶対值 }}{(\text { 前 }) \times(\text { 最低值に達省る時間 }(\text { 分 }))}\right)$ A 排泄増加一一相関係数 $=0.72$ となり，(3)場合，すなわち「単位時間に於ける血糖降下率」に最も相關してA増量があり(第 3 図)，乙 の相関は推計学的に $1 \%$ 以下の何険率で有意であつた。

その他の CA としてのNA および DAは,

A 亿比べ軽度ではあるが増加の傾向がみら れた(第 2 表)。

てれに反して DOPA およびその他の酸 性或いは中性 Catechol 体はほとんど有意 の変動を示さなかつた (第 2 表)。

次に同様な実験条件において CA 代謝 産物である MA，VMA を測定すると， Insulin による血糖降下と共にこれらもや はり尿中に排泄增加を認めるが，ての雨者 の増加の割合はAのそれには及ばなかつた。 (第 4 図)，従つて短時間内の急激な血糖降 下に対する副腎髄質の反応はA 測定によつ て最も鋭敏汇把握されるが，長期の糖尿病 コントロールの際の CA の消長は，資料の安定性からも主として MA, VMA の測定が適当と考学られる。

\section{第 4 節 糖尿病患者治療時の尿中 MA，VMA 排泄}

糖尿病患者に於て，毎日一定量の Insulin により治療を行なつた場合に，その尿中 MA 及び VMA 排 泄を経日的に測定を続けると，第 5 四に示す如く，治療を開始した初期に一過性にてれらの排泄増加か認め られ，その後は更に同様の Insulin 量の投与を続行しても增量は示さないという現象を認めた。こうした現 象は血糖降下剂として Sulfonylurea 剂（BZ55）を使用せる場合にも認めた（第6図）。 
第 4 図 血糖降下と尿的 A，MA，VMA 排泄の代表例（糖尿病例）
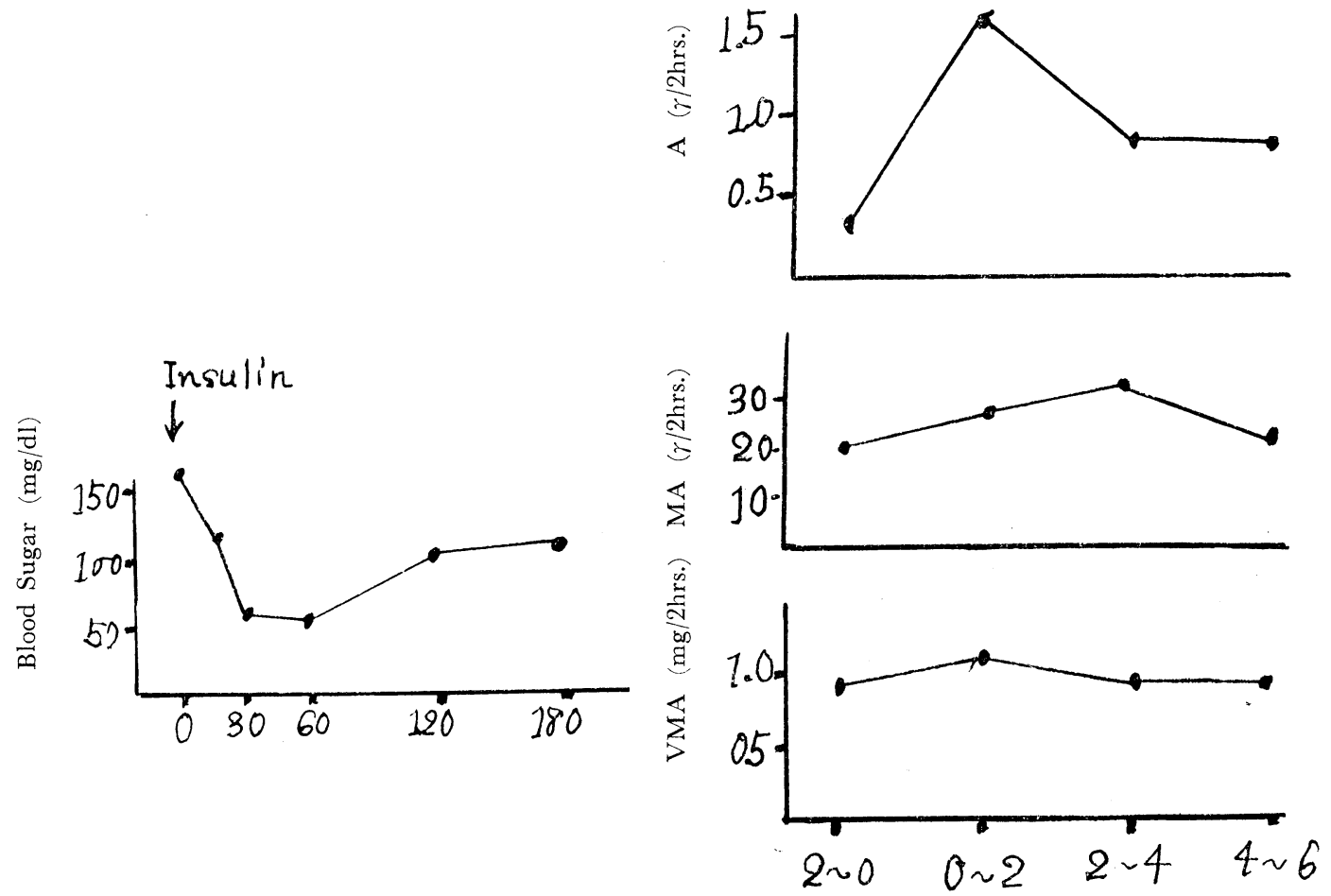

第 5 図 糖尿病葸者治療時の尿中 CA 代謝産物の排泄状沉
阪 $\bigcirc$ 栄 $\bigcirc$ 令56才
(1) Metanephrine 排悂
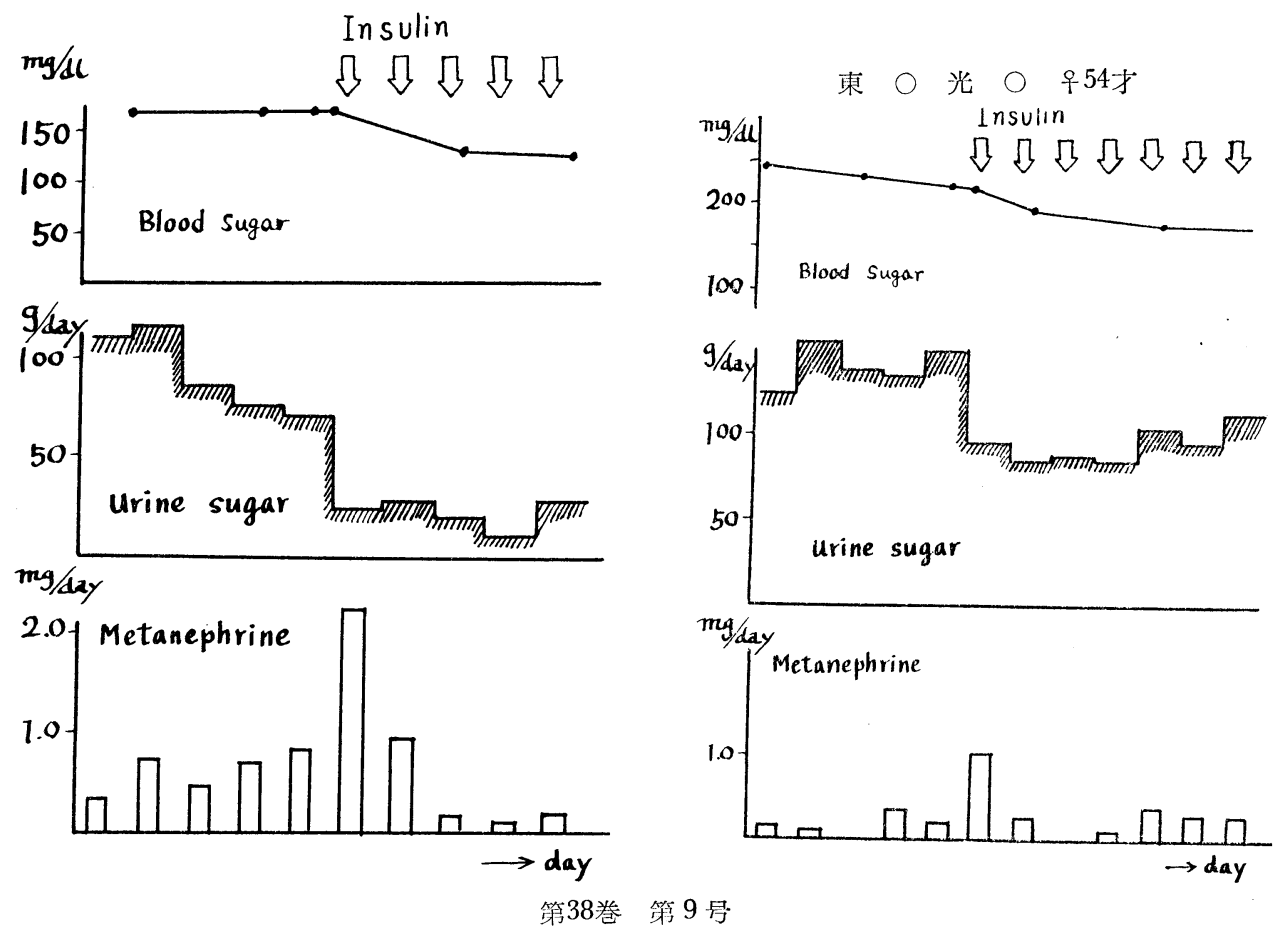
(2) Vanillyl mandelic acid 排泄

東 $\bigcirc$ 光 $\bigcirc 54$ 才早
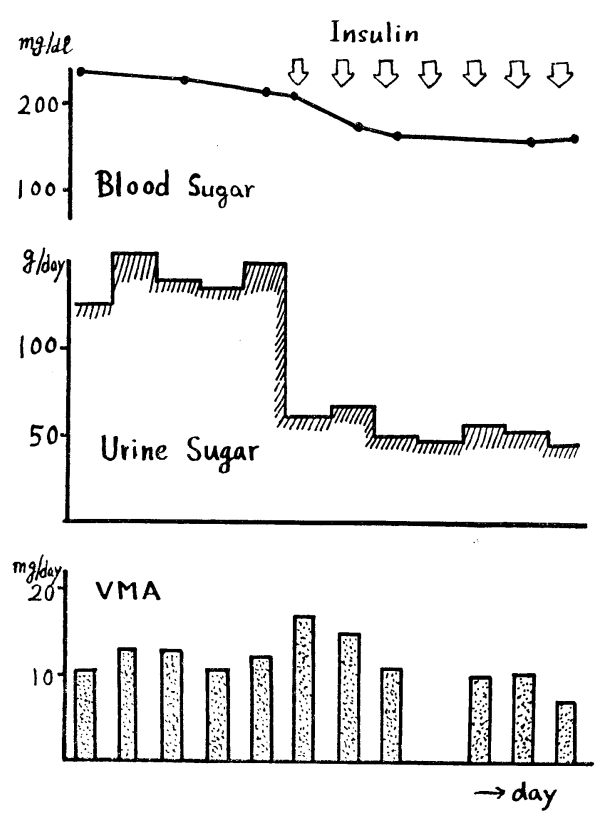

磯 $\bigcirc \bigcirc 58$ 才令

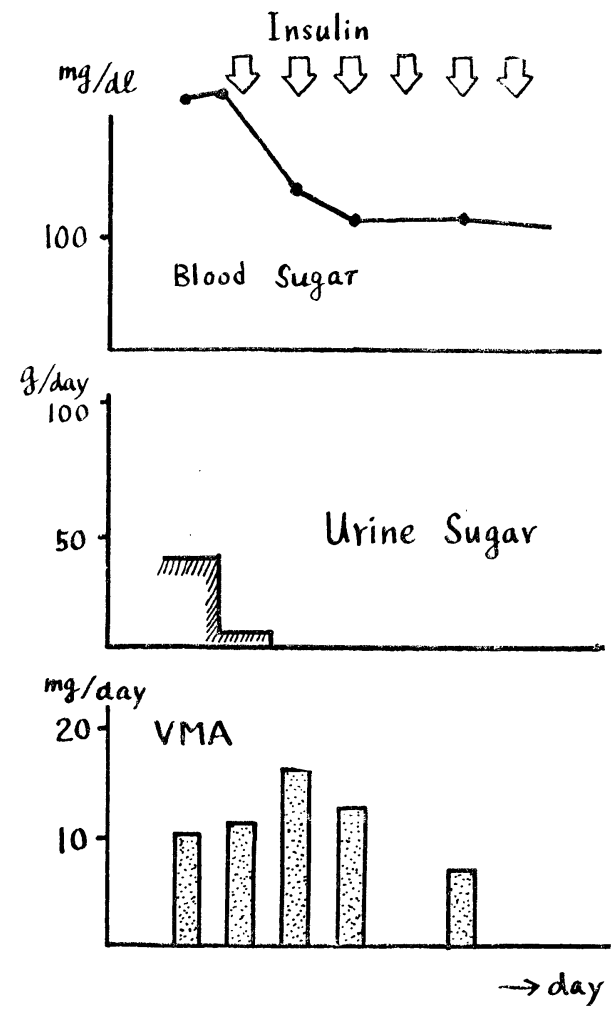

第4 章 動 物 実 験

第 1 節 研究対象及び資料採集方法

一般に体重 $2.5 \sim 3.0 \mathrm{~kg}$ 位の成熟雄性家鬼を使用した。乙れらは賉入以来，しばらくは一定の固形食を与 え, 環境的にも一定の状況に保つ様つとめた。

実験当日は絶食せしめ, 実験開始の約 4 時間程前より鬼固定台に固定し, 採尿用の持続刃テーテルを挿入 してその体位にて放置し，実験前 2 時間にわたつて採集された尿を対照尿とした.

採血或は静注は耳静脈ないし股静脈を使用した。

\section{第 2 節 Alloxan 糖尿家兔の血糖変動之A排泄}

まず高血糖状態が持続せる場合，てれよりの血糖変動が A 分泌にどの様な刺战となるかる検討し，生体の 代謝が高血糖に適応するものかどうかを検討するため Alloxan 糖尿家鬼を使用して次の実験を行なつた。

\section{第 1 項 実験方法}

発症以来約 1 週間を経過して安定状態に達した Alloxan 糖尿家鬼に，6時間にわたり Regular Insulin 6 単位を点滴注入し, 同時に Glucose の注入を行なつて尚同じレべルの高血糖を保持せしめるべく血糖を調 整した，そして次いで Glucose を中止して更に 8 単位の Insulin を追加して, 正常範囲迄の血糖降下を起 さしめた。それ以後は再び $40 \%$ Glucose を静注して血糖を上昇させた，そして採尿は 2 時間ずつ行ない， それぞれについて尿中Aを定量した。乙の間血糖は適時測定を行ない常に所望せる血糖值に調整した（第 7 図). 
第 6 図 Sulfonylurea 剂（BZ55）経口投与の際の血糖降下と尿中 Adrenalin 排泄
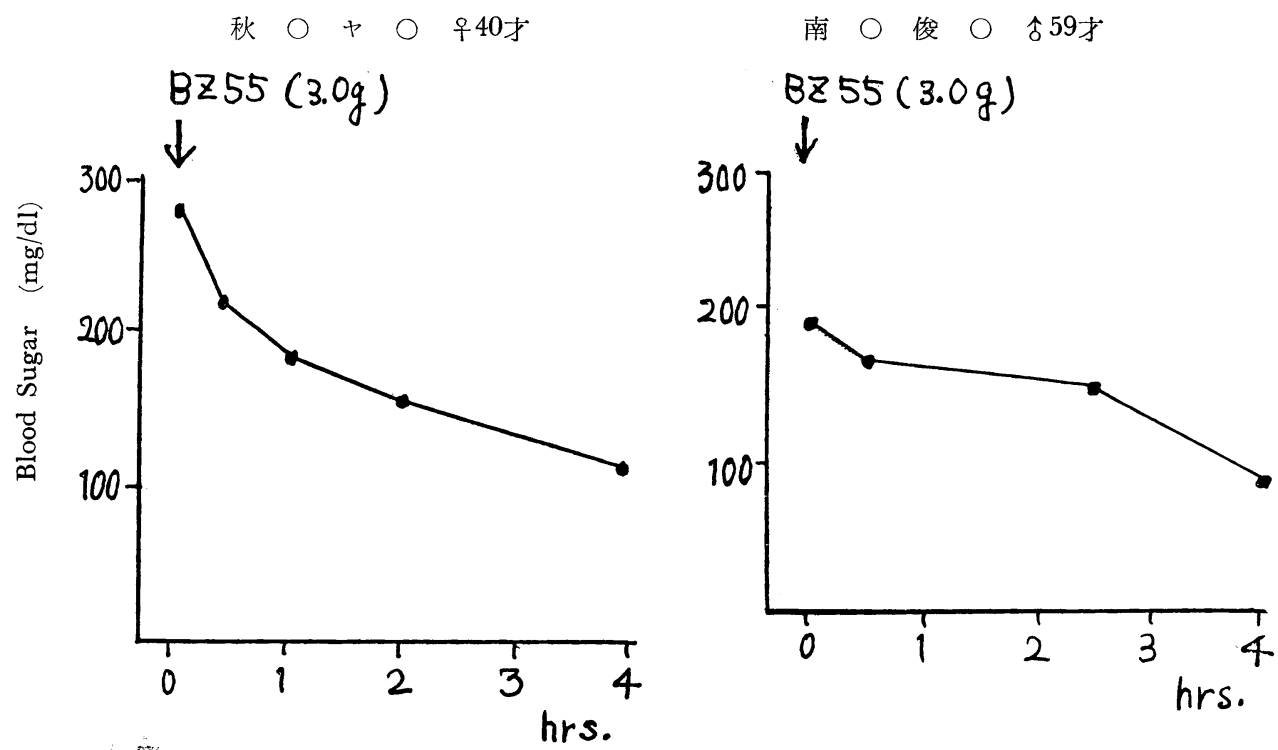
.
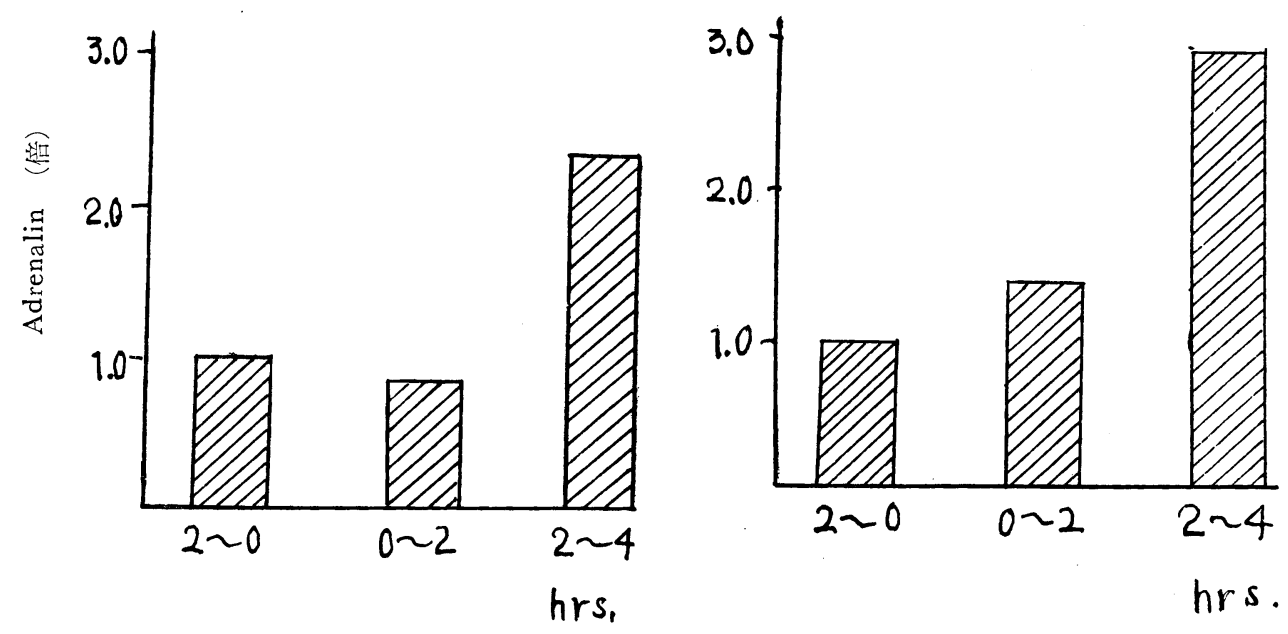

\section{第 2 項 実験成績}

この場合Aは無処置高血糖時と Insulin 投与高血糖時とで顕著な変化は示さなかつたが，Glucose 投与を 中止して正常範囲までの血糖降下が生じた期間に，前值に対して2.7倍に及ぶA排泄増量を認めた (第 7 図).

\section{第 3 節 2-Deoxyglucose 静注実験}

次に組織に於ては Insulin と同じく糖利用低下を来す 2-Deoxyglucose (2-DG と略記す) を投与し，乙 の場合の内因性 hyperadrenalemia のを起す機序を分析せんとした。

\section{第 1 項 実験方法}

組織内低血糖を起す 2-DG を $30 \mathrm{mg} / \mathrm{kg}$ の制に蒸溜水にとかしとれを静注し，その場合の前 2 時間尿に対す るAの尿中排泄を測定した。 
第 7 図 Alloxan 糖尿家鬼の血桾変動と尿中 Adrenalin 排泄（代表例）
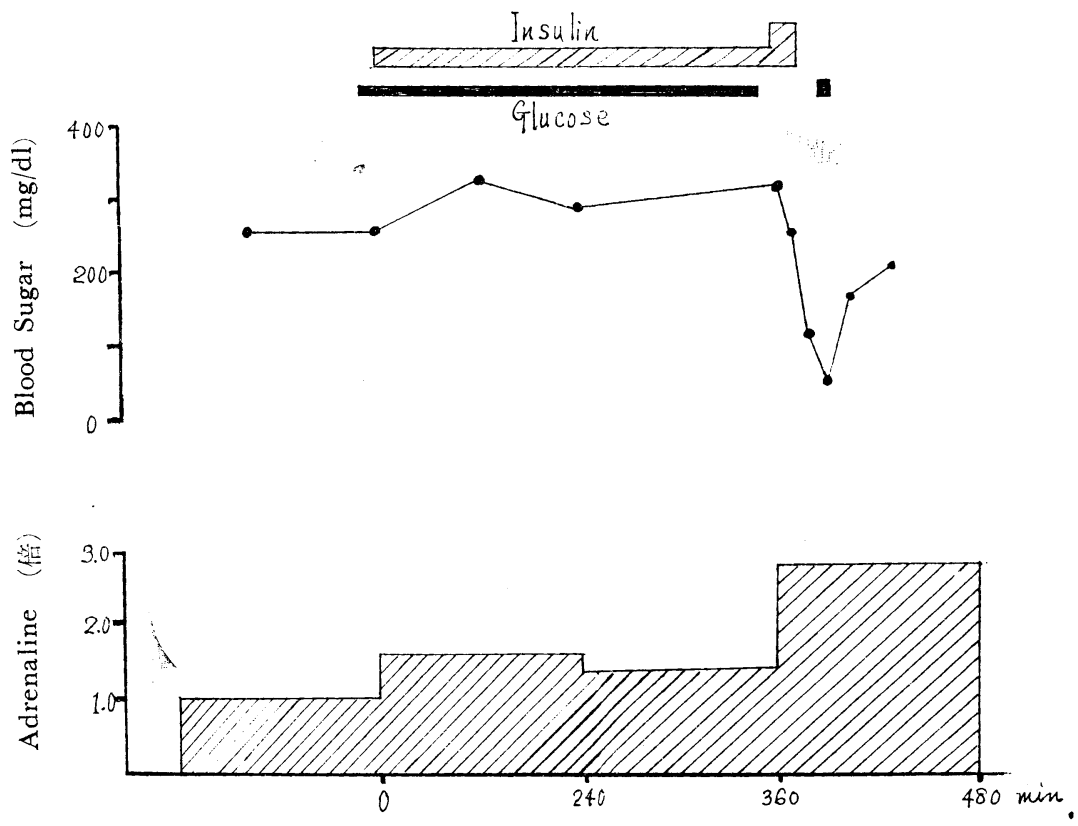

\section{第 2 項 実験成績}

2-DG を静注すると血桾は漸次上昇し, 一般に120分後では $250 \sim 300 \mathrm{mg} / \mathrm{dl}$ の值に

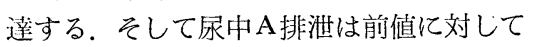

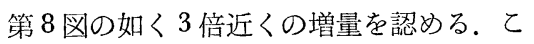
の場合2-DG 投与量を種々変更して，それ ぞれの場合の尿中A排泄增加を測定し静注 2-DG 量と排泄A增加との log dose response curve を画くと，第 9 図の如くなる. つまり静注の場合 $10 \mathrm{mg} / \mathrm{kg}$ の量を境とし てA排泄増加は2-DG と共㵔明となつて くる.

\section{第 4 節 2-Deoxyglucose 頸動脈注射実験}

かかるA分泌促進が主として中枢の糖利 用低下を刺㦸とするものならば，頸動脈注

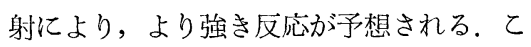
れを確認するため, 上記静脈注射にて顕著 なA分泌反応は来さない最大量の2-DG を 頸動脈㳊投与する実験を行なつた。

\section{第 1 項 実験方法}

正常家鬼を固定台に固定し，前頸部を切 開して右或いは左の総頸動脈を露出せしめ (との場合近くに存在する迷走神経に接触 せぬ椂注意する)，乙れに細い注射針にて $2-D G 10 \mathrm{mg} / \mathrm{kg}$ (蒸溜水 $1 \mathrm{ml}$ に溶解) を 動脈注射する。

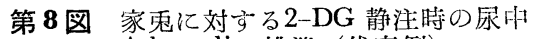
Adrenalin 排泄（代表例）

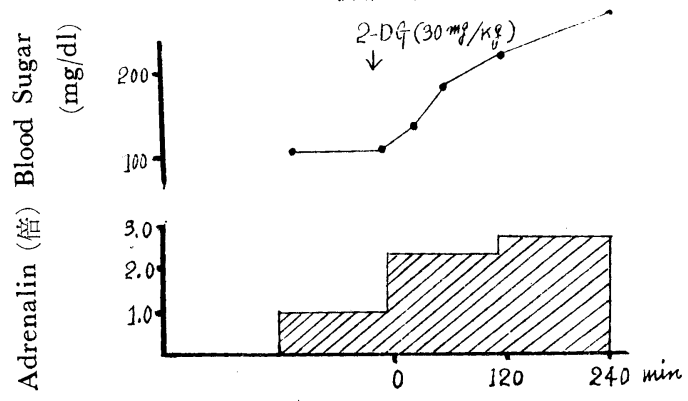

第 9 図 2-DG 投与量と尿中 Adrenalin 排泄 (静注の場合)

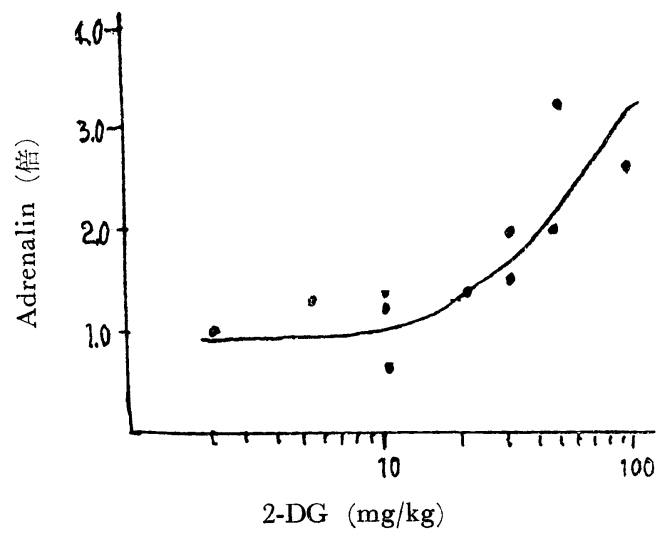

第38巻 第 9 号 


\section{第 2 項 実験成績}

2-DG 頸動脈注射を行なうと，静脈注射では殆んどA排泄増加を認めない $10 \mathrm{mg} / \mathrm{kg}$ の量に於ても，第10 図の如く顕著なA排泄増加を示した，対照実験として2-DG 溶液の代りに生理食塩水を頸動脈注射した際， 尿中A排淮には著明な変動はみられなかつた。

第10図 2-DG $(10 \mathrm{mg} / \mathrm{kg})$ 娄頸動脈及び静脈に投与した際の

尿中 Adrenalin 排浛 (家鬼)

静脈注射

頸動脈注射

(倍)

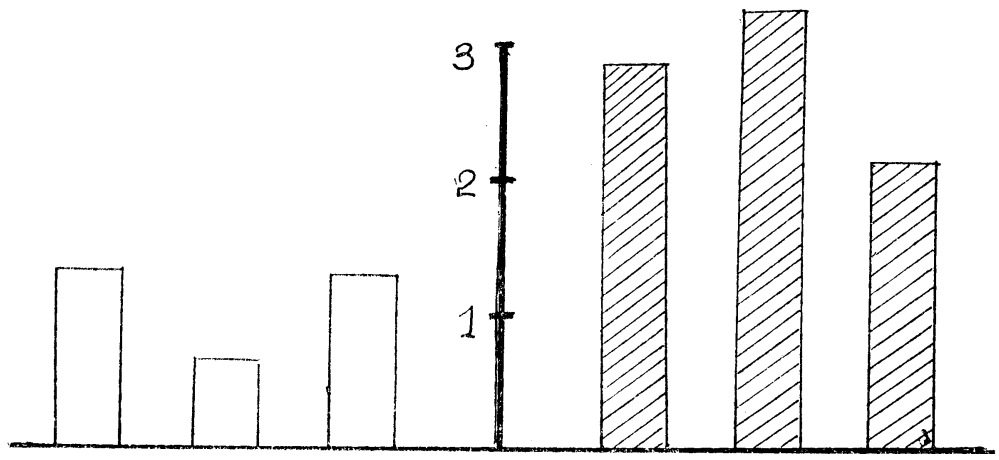

（前 2 時間尿に対する比）

\section{第 5 節 両側副腎神経切断家鬼に対する2-DG 静注実験}

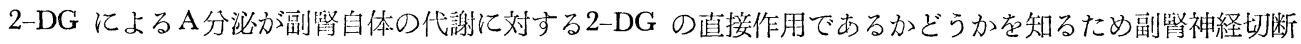
を行なつて検討した.

\section{第 1 項 実験方法（副腎神経切断）}

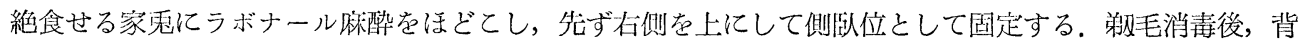
筋の外側で肋骨开直下より甥幹と平行に約 $5 \mathrm{~cm}$ 切開し，血管を結禁しながら内部に進み，後腹膜にある腎

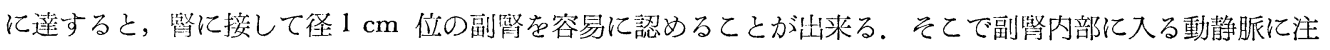
意しつつ副韰周间より進入せる神経線維を切断し，手術創を縫合して第一次手術を終える。次に 4 〜日後

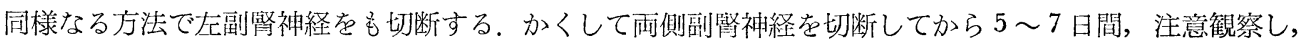
健康を回復せしてとを確かめて実験に供した。

一方対照としては，同様に背部切開を行ない深部臟器迄手触せし家乘を使用した。

\section{第 2 項 実験成績}

両側副筒神経切断家鬼に2-DG30mg/ kg を静注すると，血糖上舁は20〜30 mg/dl 程度に止り 2 時間後に は既にほとんど正常化し，対照家鬼とは著明な相異を示した。 そしてての時両側副腎神経切断家鬼では，A 排泄増加は全く認められなかつた (第11図).

\section{第 6 節 Insulin 静注時 Glucose 投与によつて血糖降下を防止した場合の A 排泄}

Insulin が直接 A の releaser となるか不かを検討した.

\section{第 1 項 実験方法}

正常家鬼に Regular Insulin 0.3 I.U./kg 静注する際，同時に40\% Glucose 液 $10 \mathrm{ml}$ を注入し，更に30分 後にも 40\%液 Glucose 液 $10 \mathrm{ml}$ を注入して血糖を全く降下せしめない状態において, Insulin 注射前 2 時間 及び注射後 2 時間ずつ 3 回採尿して尿中Aを定量した。

\section{第 2 項 実験成績}

この場合 $\mathrm{A}$ 排泄増加は全く認めなかつた（第12眓)。 


\section{第 5 章 総括並びに考按}

Insulin の大量投与によつて低血糖に至 らしめた場合, 副䐌髄質の分泌が充進し低 血煻症状を起すととを示した動物実験の報 告は多いが，臨床観察においては糖尿病患 者に Insulin を注射した後, 血糖値がなお $200 \mathrm{mg} / \mathrm{dl}$ 以上でありながら低血糖症状の 発現をみた sunderman 等の報告 ${ }^{23)}$. 血糖値 が50mg/d1以下の低血糖を持続しながらほ とんぞ無症状であつた著者等の症例（von Gierke 病 ${ }^{24)}$, Maddock, ${ }^{25)}$, Rabinowitch \& Peters の報告等 ${ }^{26)}$, 血糖値之臨床症状との 間の奇異な解離現象が認められており，低 血糖症状と血糖值の変動との間の統一的な 兒解を示した記載はまだ見当らない。

著者は糖尿病患者を含めた広い範囲の空 腹時血糖分布を有する実験対象群に対して 0.1 I.U. $/ \mathrm{kg}$ という生理量の Insulin を静 注し, 血糖変動と $\mathrm{CA}$ 分泌状態との関係を 追求した，先ず Insulin が releaser の如 き直接作用を有するものでないてとは， Insulin 注射仙つても血糖降下を惹起し 得なかつた例では $\mathrm{A}$ 排泄增加はみられない という事実, 又家鬼で Glucose 及び Insulin の同時投与により血糖降下を阻止した場合 にもA増加を認めないという事実より，A 增量はやはり直接 Insulin の作用によるも のではなく寧ろ Insulin による血糖変動に 基因するものと解さなければならない，そ こで血糖変動に関する諸量とA増量との関 係を分析した結果, 血糖降下速度を前値で 除した値, 即ち「単位時間における血糖降 下率」に最もよく相関してA増量の観られ るてとが結論された。これによつて明らか な如く，血糖の降下が必ずしも「低血糖」の

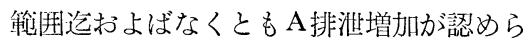
れ，乙れは糖尿病患者においてむしろ一般 的であつた。しかし同時に，血糖降下の絶 対量が変らなくともその降下速度および前 值の高低により副腎髄質に対する作用も異 なることから，糖尿病患者の如く血糖の前 值も高く降下速度も緩徐な場合は，一般に
第11図 両側副珡神経切断家鬼化対する 2-DG 投与 神経切断例

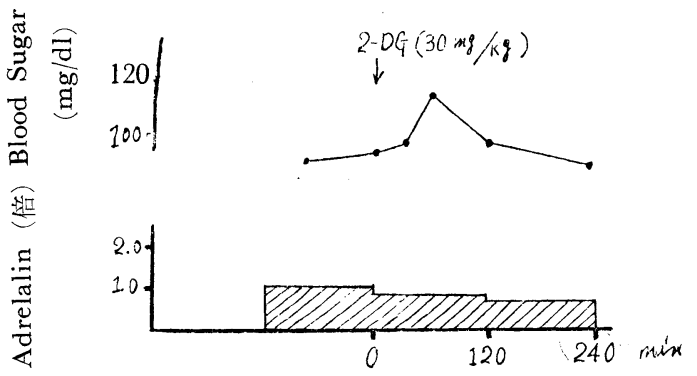

対照例

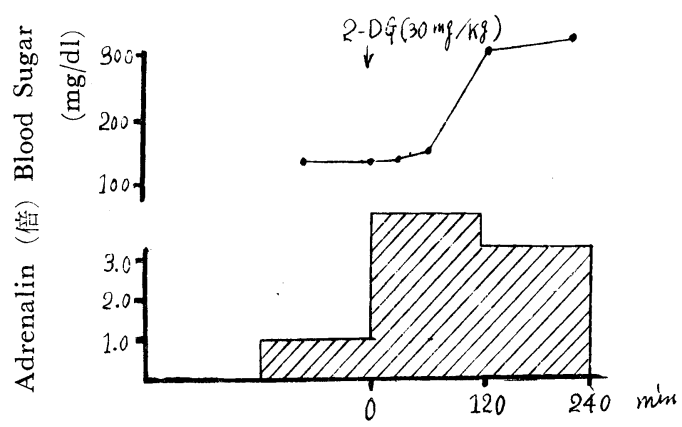

第12図 Insulin 静注後血楉降下老防いだ場合の 尿中 Adrenalin 排泄（家鬼）
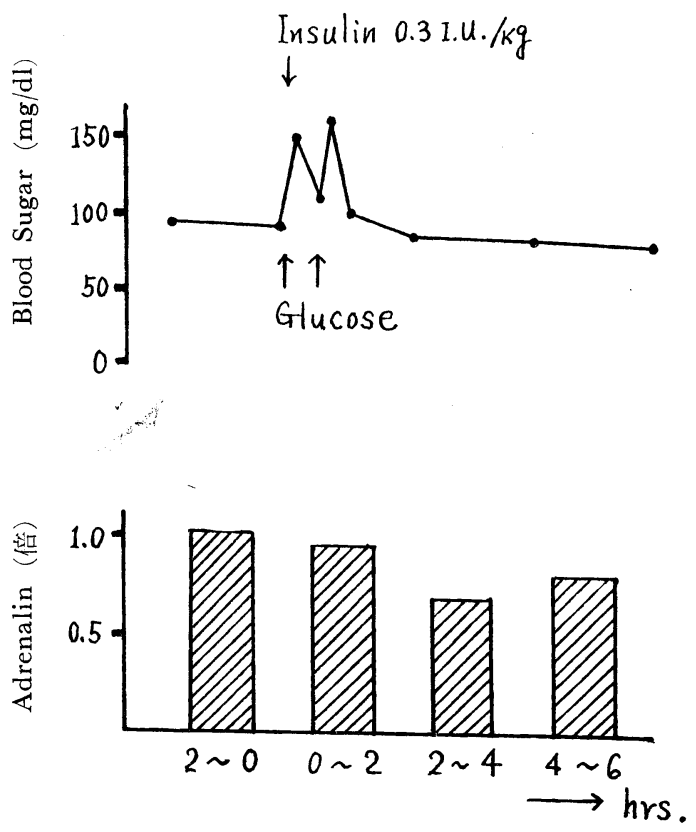

第38巻 第 9 号 
A分泌刺战は軽度である，結局「単位時間における血糖降下率」にはA 増加に関する因子として，次の $3 つ$ を含んでいる. 即ち空腹時血糖值, 血糖降下率及び降下速度である。空腹時血糖值は各個人に特有であり,

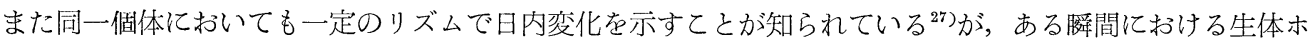
メオスタージスの基準として大きな意味を有するてとが，以上の成績からも理解されるのである．外部の因 子によりこのホメオスタージスの破られる場合にA分泌圥進がみられるものであり，著者の認めた糖尿病患 者に対する Insulin 治療時，尿中 CA 代謝産物が初期の高血楉状態から Insulin 治療を開始して血糖下降

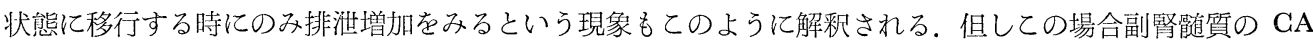
の恢復速度が問題となり，大量の Insulin で䚛質のA を著減せしめた後の恢復はかなり遅いといわれている 28)-30). しかしこの場合の Insulin の使用量としては一般に非常に大量であり，Udenfriend ${ }^{300}$ などは体重 $\mathrm{kg}$ 当り 1.8 単位を家鬼に投与している. 著者の臨床例では $0.2 \sim 0.31 . \mathrm{U} . / \mathrm{kg}$ 位のもので極めて少量である，又 Elmadjian $^{31)}$ なぞは一定量の Insulin を連続 5 日間静注すると，尿中A排泄が次第に減少した例を報告して いるが，てれとてもAは第 5 日目においても明らかな分必を示している．従つて著者の例は少量かつ皮下注 射でもあるので, 副腎㗓質の衰微による減少というよりは，やはり分泌機序に対する刺㦸そのものの減少に よると考光る方が妥当と云える。最近 Somogyi ${ }^{32333)}$ は糖尿病治療の際, 過量 Insulin 投与により下垂体一 副㹂系の血糖上昇ホルモンの放出をうながし，その為に糖尿病自体にむしろ覀影響をおよぼすということ を強調し，かかるてとは低血糖の度合が軽く，無症状な場合でも有害で，尿糖および血糖値に paradoxical な增覀現象を呈すると述べているが，著者の解䐆からすれば，Insulin の使用に当つて初期少量，漸次増量 し，しかも持続 Insulin 製剤等を使用して頻回の血糖変動を出来るだけ避け，漸進的に血糖値を正常化せし めるのが望ましいと考朰れる。

次にA分泌対する血糖降下速度の関与であるが，A増加に対して単なる血糖降下率よりも「単位時間に おける血糖降下率」が A 分泌によく相関する更に重要な因子と推定される。血糖降下率と A 増加の相関は臨 床実験の場合有意とはいえない，従つて Insulin 投与後の血糖降下相においては，血糖降下速度がA增加 に関する一つの因子を構成していると考觉なければならない，しかし低血糖の持続相においてもやはりA分 泌の充進がみられるととを, 家鬼における実験に於て認めたが，その程度は血糖降下相程著明ではない。

以上の他, Insulin による血糖降下時, A以外の CA について倹討する際，先ずAおよび NA の增量の 間に一定の関聯性があるか否かをみた所，一般にAの增量の軽度である例では NA はほとんど増加せず， Aの著明な增量のある例では NA の軽度の增加を認めた。これは Elmadiian 等泫のの観察とは相反している

(但し Elmadjian 等の測定法は，Bioassay である）が，Goldfien 等 ${ }^{34)} の$ 成續とよく一致している。乙の ようなInsulin 投与後の成績と対照的に, Metacholine 投与後の低血圧に対しては主として NA が反応す るという5゙311. A はその pressor effect が NA の1/2であり, 反対に hyperglycemic effect が NA の約 4 倍である事実 ${ }^{55}$ を対置するとき，Insulin 投与時のような特別な剌㦸に対する CA の反応を単に非特異 的な Stress 反応として理解することは困難なようで, 矢張り血楉調節反応の一環として解釈すべきであろ う。 その他の DA，DOPA および他の酸性中性 Catechol 体に関しては，その生理的役割および意義がな お具体的ではなく, 明確な考察は致しがたい，涏つてともかく Insulin 投与による血糖降下の場合，一次 的な反応がAであることは結論し得る所である。

更に GA 分泌反応が中枢と如何なる関聯があるかを考察してみる.

Phosphoglucoisomerase の阻害郕で，生体に投与するとGlucose の利用障㥂を来し，組織内低血糖を起 すと考觉られている 2-DG ${ }^{36)}$ を家鬼に静注すると，血糖上昇と尿中 Aの著明な排泄增加とを認め，Insulin 低血糖と同しく糖利用の低下を来し，内因性の hyperadrenalemia を招来すると考えられる．てれに対し て中枢の receptor 考慮すべきか否かは，脳及び体部の交叉灌流により2-DG に対する反応を見るのが理 想的であるが，副腎喵質分泌の变化を正確に把握するには相当高度の安定した生理的状態が要求される. 従 つて著者は強度の非生理状態を強制される交叉灌流実験をさけ，2-DG を頸動脈に投与し，一般静脈注射 よりより強い A 排泄增加を得たのである。つまり Insulin の洔にしろ 2-DG の時にしろ, 中枢性の組織 


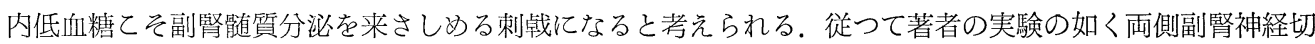
断家鬼に対する2-DG 投与の場合には A排泄増加は阻止され，副腎髄質自体の代謝障碍は A分泌刺㦸とはな らないととを示している。

糖尿病の病態生理にA カ溡に役割を演じているという証明はないが，血糖降下に伴う A 分泌増加が，中枢 における糖代謝障碍の反映であるとすれば，Insulin 注射後降下した血糖值がなお正常血糖範囲に止まるに

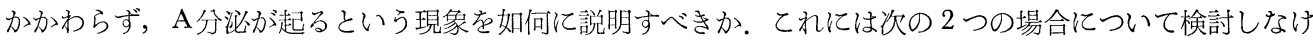
ればならない，先ず Insulin が中枢神経系に直接作用を有するか否かは重要な問題であるが，従来より血糖 を介する間接作用の面が強く考えられ，又 $I^{131}$ 標識 Insulin の脳内分布が他の部分より非常に少なく $\left.{ }^{37}\right)^{388}$, 脳内に殆んど移行しない事より直接作用はあまり問題にされていなかつた。しかしラッテの脳組織切片にお いては Glucose uptake を Insulin は增加せしめ39)，又ラッテの遊離脊髄分節でも Glucose uptake を増加

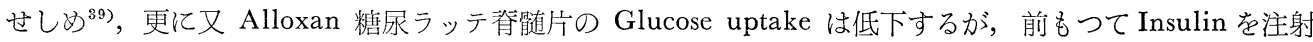
すると，ての Glucose uptake 低下は是正し得る ${ }^{39}$ 等の事実が知られており Insulin の中枢神経系位対す る直接作用を全く否定するわけにはいかない，そてで先の現象を考察する場合一応中枢も Insulin dependent であるといら前提のもとに中枢では Insulin による糖代謝の是正が末梢より遅れて発現するという推 論も成立する，つまりそのため Insulin による血糖降下時，末梢では糖利用は促進しているが中枢ではま だ促進せず，かえつて血糖低下のため糖利用が障碍されると云う場合が考光られるのである。もう一つの考 えとしては，高血糖状態に中枢の代謝が適応した結果，正常範囲迄の血糖降下でも $\mathrm{A}$ 分泌が起ると解釈する 方法がある。著者の Alloxan 糖尿家鬼に対する血糖降下実駼(第7図)はこの間の現象を明らか汇説明する. 即ち Insulin 補給に上り糖尿病的代謝位相を是正し，しかも尚高血糖状態を保持せしめた場合に，次に起 す血糖降下が副腎䯣質刺战となり，著明なA分泌を招来したというととは，糖尿病状態に於ては中枢の代謝 pattern がそれに “gewöhnen”されていて，てれよりの血糖降下が例えそれが正常範囲迄であつても副腎 蹎質分泌を招来せしめる適応刺㦸となることを明確に示している，そして糖尿病患者治療の際，治療初期に のみ一過性の CA 代謝産物が增量するという現象も，ての“Gewöhnung”の考光により，よく理解する ととが出来る。

\section{第 6 章 結 論}

生体に Insulin を投与した際，尿中 GA 排泄増加がみられるが，ての場合血糖が正常值以下に低下する ことが CA の分泌刺㦸となると考光られている。しかし臨床上，糖尿病患者の Insulin 治療中，血糖が正 常值以下に低下しない場合にも，時に低血糖症状の発現することが経験され，乙の際にも低血糖時同様， GA 分泌の㠵進があると推定される。そこで糖尿病患者を含めた広い範囲の空腹時血糖分布を有する実験対 象群に対して，血糖値の変動と原中 $\mathrm{GA}$ の消長との関係を分析し，更に尿中 $\mathrm{CA}$ 増量の機序についても検 討を行なつた結果，次の如き成績を得た。

1) Insulin 投与時のA分泌は，Insulin が releaser の如き直接作用を有する為ではなく，血糖変動自体 がA分泌関与する。

2 ）そして正常人および糖尿病患者に，体重 $k g$ 当り0.1単位の Insulin を静注した場合，血糖降下に伴う 尿中 A排泄は「単位時間における血糖降下率」に高度に相関する。

3) 血糖降下剂による 糖尿病患者治療の際，その初期にのみ一過性のMA，VMA 排泄増加を認める。

4 ）糖尿病患者にて血糖降下時，低血糖に至らずしてA排泄増加の起るのは，主として中枢が高血糖状態 に適応しているためと考光られる実験成績を得た。

稿を終るに臨み，御指導を睗わつた恩師故木谷教授に衰心より謝意を表し，伊せて御愁切な御教示並びに 御校閲を賜つた大阪大学医学部薬理学教室今泉礼治教授に深く感謝致します。

本論文の要旨は第 2 回日本桾尿病学会総会，第 8 回日本内分泌学会西日本地方会，第 4 回日本糖尿病学会 
総会, 第35回日本内分泌学会総会に扎いて発表した。

文献

1) GANNON, W.B., M.A. McIVER. and S.W. BLISS : Am. J. Physiol., 69 : 46-66, (1924).

2) HOUSSAY, B.A., E.A. MOLINELLI and J.T.LEWIS : Rev. Asod. med. argent., 37 : 486, (1924).

3) ABE; Y. : Arch. exper. Path. u. pharmacol., 103: 73-83, (1924).

4) BURN, J.H., D.E.

HUTGHEN and R. H. O. PARKER : Brit. J. Phramacol., 5 (4) :417-423, (1950). 5) ELMA-

DIAN, F., E.T. LAMSON H. FREEMAN R. NERI and L. VARJABEDIAN : J. Clin. Endoclinol. \& Metab., 16 (11) 876-886, (1956). 16 ) EULER, U.S.v. and R. LUFT : Metadolism,1 (6) : 528-532, (1952). 7) PITKÄNEN,E. : Acta physiol. Scand., 38 : Suppl. 129, (1956).

8) LOEW, O. : Biochem. Zschr., $85: 295$, (1918). $\quad$ 9) PAGET, M. : Bull. Sc. pharm., $37: 537$ -538. (1930). 10) LUND. A. : Acta pharmacol. etToxicol., $5: 231-247$, (1949). 11)

EULER, U.S.v. and I. FIODING : Acta Physiol. Scand., 33, Suppl., $118: 45-56$, (1955). 12) WEIL-MAIHERBE, H.and A.D. BONE : Biochem. J., $51: 311-318,(1952) . \quad 13)$ 佐野馨，蒲生 達三, 橋本裕一：日内分必誌，35（1）：86～93，(1959). 14）中島一彦，大阪大学医学雑誌，12 (3) 57 63, (1960). 15) AXELROD, J. : Phamacol. Rev., 11:416, (1959). 16) PISANO, J.J. : Clin. Chim. Acta. 5 : 406-414, "(1960). 17) BERTLER, A. : Clin. Chim. Acta, $4: 456$, (1959). 18) 柿本泰男 : personal communication. 19) ARMSTRONG, M.D., et al. : Biochim. biophys. acta, $25: 422$, (1957). 20) STUDNITZ, W.V. and A. HANSON : Scand. J. Clin. Lab. lnvest., $11: 101$, (1959). 21) SANDLER, M. and G.R.J. RUTHVEN : Lancet, II : 114, (1959). 22) KIRSHNER, N., McG. GOODALL and L. ROSEN : J. Pharmacol. Exp. Therap., 127 (1) : 1, (1959). 23) SUNDERMAN, F.W., J.H. AUSTIN and P. WILLIAMS : J. Clin. Invest. 11 (6)：1261-1272，(1932). 24）垂井清一郎，奥野蒐一，進士義剛， 梅谷部男, 中川史子：日内会誌，48（9）：1513～1514，(1959)。 25) MADDOGK, S.T. : J. A. M.A., 91 (9) : 616-621, (1928) 26) RABINOWITCH and PETERS : Am. J. Med. Sci., $178: 29$ ，(1929), cited by Joslin. 27) 平田幸正: 綜合臨床，8 (1) : 28３6，(1959) 28) BURN, J.H., D.E. HUTCHEN and R.H.O. PARKER : Brit. J. Pharmacol., 5 : 417-423, (1950). 29) HÖKfELT, B. : Acta Physiol, Scand., 25 : Suppl.,92, (1951). 30) UDENFRIEND, S., J.R. COOPER, G.T. CLARK and J.E. BAER : Science, $117: 663-665$, (1953). 31) ELMADJIAN, F., J.M. HOPE and E.T. LAMSON : Rec. Prog. Horm. Res., 14 :513-553, (1958). 32) SOMOGYI, M. : Am. J. Med., $26: 169-191$, (1959). $\quad 33$ ) SOMOGYI, M. : Am. J. Med., $26: 192$ -198, (1959). 34) GOLDFIEN, A.,M.S. ZILELI, R.H. DESPOINTES and J.E. BETHUNE : Endocrinol., 62 (6) : 749-758, (1958). 35) RONZONI, E. and S. REICHLIN : Am. J. Physiol. 160 (3) : 490-498, (1950). 36) ARNE, N.W., R.D. DOUGLAS, I.N. HENRY and J.B. : J. Biol. Chem., 224 (2) ; 963-970, (1957). 37) ELGEE, N.J. R.H. WILLIAMS and N.D. LEE : J. Glin. Invest., $33: 1252,1954 . \quad 38)$ HAUGAAD, N., M. VAUGHAN, E.S. HAUGAAD and W.G. STADIE : J. Biol. Chem., 208 : 549, (1954). 39) RAFAELSEN, O.J : Metabolism, 10 (2) : 99, (1961). 